\title{
PRODUCTIVITY IMPROVEMENT OF LEATHER PRODUCTS INDUSTRY IN BANGLADESH USING LEAN TOOLS: A CASE STUDY
}

\author{
Nadia Akter SWARNA, Md. Abu SAYID MIA* \\ Department of Leather Products Engineering, Institute of Leather Engineering and Technology, University of Dhaka, Dhaka \\ 1209, Bangladesh
}

Received: 03.04.2018

Accepted: 11.08 .2018

https://doi.org/10.24264/Ifj.18.3.7

PRODUCTIVITY IMPROVEMENT OF LEATHER PRODUCTS INDUSTRY IN BANGLADESH USING LEAN TOOLS: A CASE STUDY

ABSTRACT. There is great potential for the leather industry in Bangladesh to become one of the country's major foreign exchange earners, experts say. After readymade garments (RMG), productivity improvement can help to enrich profit of a leather products industry by minimizing excess work and developing a new method for particular operation. Nowadays, productivity improvement is a popular topic for any kinds of industry. Therefore, improving productivity is one of the main concerns of leather products industries. Lean manufacturing tools are most important tools that can help to increase productivity in leather products industry. In Bangladesh, few industries use these lean tools which can be proved as a real beneficial one. Hence, this study addresses the implementation of lean principles in a leather goods manufacturing industry in order to evaluate present process cycle efficiency (PCE), lead time and productivity prior to developing an improved strategy to bring the improved PCE, productivity and to reduce the lead time. By applying lean tools in the industry at the production line for bi-fold wallet, productivity has been improved by $85.42 \%$. At the beginning state, the PCE was found $38.19 \%$ and after the implementation of lean tools, it would be $77.51 \%$ and lead time would also be reduced by $46.68 \%$ evaluated by takt time, bottleneck analysis, cause-effect analysis and Pareto analysis. The production flow was optimized by minimizing several non-value-added (NVD) activities such as bottlenecking, machine breakdown, queue time, waiting time, material handling time, etc.

KEY WORDS: productivity, lean tools, PCE, lead time, Pareto chart, wallet production line

\section{ÎMBUNĂTĂȚIREA PRODUCTIVITĂȚII INDUSTRIEI PRODUSELOR DIN PIELE DIN BANGLADESH UTILIZÂND INSTRUMENTE SUPLE: UN STUDIU DE CAZ}

REZUMAT. Industria de pielărie din Bangladesh are un mare potențial de a deveni unul dintre sectoarele cele mai profitabile din țară, conform experților. După îmbrăcămintea de masă, îmbunătățirea productivității poate contribui la creșterea profitului industriei produselor din piele prin reducerea la minimum a excesului de muncă și prin dezvoltarea unei noi metode pentru o anumită operațiune. În prezent, îmbunătățirea productivității este un subiect popular pentru orice tip de industrie. Prin urmare, îmbunătățirea productivității este una dintre principalele preocupări ale industriei produselor din piele. Instrumentele suple de producție sunt cele mai importante instrumente care pot contribui la creșterea productivității industriei produselor din piele. În Bangladesh, puține industrii folosesc aceste instrumente suple, care pot fi de real folos. Prin urmare, acest studiu abordează implementarea unor principiilor suple în industria de fabricare a articolelor din piele pentru a evalua eficiența ciclului de proces (PCE), timpul de producție și productivitatea înainte de a dezvolta o strategie pentru a îmbunătăți PCE și productivitatea și pentru a reduce timpul de producție. Prin aplicarea instrumentelor suple în industrie în linia de producție a portofelului cu îndoitură, productivitatea a fost îmbunătățită cu 85,42\%. La început, PCE a fost de 38,19\%, iar după implementarea instrumentelor suple, ajunge la $77,51 \%$, iar timpul de execuție se reduce cu 46,68\%, evaluat în funcție de timp, analiza blocajelor, analiza cauză-efect și analiza Pareto. Fluxul de producție a fost optimizat prin reducerea la minimum a câtorva activități care nu adaugă valoare (NVD), cum ar fi blocajele, defectarea mașinilor, timpul de așteptare, timpul de manipulare a materialelor etc.

CUVINTE CHEIE: productivitate, instrumente suple, PCE, timp de execuție, diagramă Pareto, linie de producție a portofelelor

\section{AMÉLIORATION DE LA PRODUCTIVITÉ DE L'INDUSTRIE DES PRODUITS EN CUIR AU BANGLADESH À L'AIDE D’OUTILS DE GESTION ALLÉGÉE: UNE ÉTUDE DE CAS}

RÉSUMÉ. L'industrie du cuir au Bangladesh a un grand potentiel pour devenir l'un des secteurs les plus rentables du pays, selon les experts. Après les vêtements de masse, l'amélioration de la productivité peut contribuer à la croissance des bénéfices de l'industrie des produits en cuir en minimisant l'excès de travail et par l'élaboration d'une nouvelle méthode pour une opération. À l'heure actuelle, l'amélioration de la productivité est un sujet populaire pour tous les secteurs. L'amélioration de la productivité est donc l'une des principales préoccupations de l'industrie des produits en cuir. Les outils de gestion allégée sont les outils les plus importants qui peuvent aider à accroitre la productivité de I'industrie des produits en cuir. Au Bangladesh, peu d'industries utilisent ces outils qui peuvent s'avérer utiles. Par conséquent, cette étude porte sur la mise en œuvre des principes de la gestion allégée dans la fabrication des produits en cuir pour évaluer l'efficacité du cycle de processus existant (PCE), le temps de la production et la productivité avant d'élaborer une stratégie pour améliorer le PCE et la productivité et pour réduire le temps de production. En appliquant les outils de gestion allégée à la ligne de production de portefeuilles, la productivité a été améliorée de $85,42 \%$. Au début, le PCE était $38,19 \%$, et après la mise en œuvre des outils de gestion allégée, il atteint $77,51 \%$ et le temps d'exécution est réduit de $46,68 \%$, évalué par temps de prise, analyse des goulots d'étranglement, l'analyse cause-effet et l'analyse de Pareto. Le flux de production a été optimisé en minimisant les multiples activités et les temps sans valeur ajoutée tels que les goulots d'étranglement, les pannes de machines, les temps d'attente, les temps de traitement des matériaux, etc.

MOTS CLÉS : productivité, outils de gestion allégée, PCE, temps d'exécution, diagramme de Pareto, ligne de production de portefeuille

\footnotetext{
* Correspondence to: Md. Abu Sayid MIA, Department of Leather Products Engineering, Institute of Leather Engineering and Technology,
} University of Dhaka, Dhaka 1209, Bangladesh, E-mail: emsayid@gmail.com, Tel: +8801674772545 


\section{INTRODUCTION}

Manufacturing is a vital sector in society, irrespective of being a high or low-income economy [1]. The leather sector is playing a vital role in our national economy, earning us huge amounts of export earnings. Most leather goods and footwear manufactured here are export-oriented. According to the Export Promotion Bureau (EPB), leather exports totaled USD 116.73 million in the last fiscal year 2016-2017; the amount was USD 92.50 million the previous year [2]. In the world, it is one of the leading manufacturing industries based on raw material, geographical condition, and workforce and is highly favorable for the growth of leather products industry. The demand for processed leather products is rapidly increasing in the busy world and consequently, it seems a rapid expansion of leather products industry in Bangladesh as well as in other countries. It needs several production steps to produce the finished goods from raw materials. Today higher productivity achievement is a very important factor for the production field. With the higher productivity, other various factors must be taken into consideration in manufacturing industries such as global competition, lead time and customer need in terms of quality and quantity $[3,4]$. Continuous improvement with or without capital infusion necessitates competitive manufacturing [5]. Lean manufacturing is based on the Toyota Production System developed by Toyota which focuses on eliminating waste, reducing inventory, improving throughput, and encouraging employees to bring attention to problems and suggest improvements to fix those [6]. Lean manufacturing has been increasingly applied by leading manufacturing companies throughout the world. A core concept of lean manufacturing is pulling production in which the flow on the factory floor is driven by demand from downstream pulling production upstream. Some of the changes required by lean manufacturing can be disruptive if not implemented correctly and some aspects of it are not appropriate for all companies $[7,8]$. A lean manufacturing facility is capable of producing the product in only the sum of its value-added work content time [9]. The main scope of lean manufacturing is to eliminate waste and reduce the cycle time to increase the profit and competitiveness by increasing the production and decreasing the cost of product [10]. On the other hand, applications of lean manufacturing in the continuous process sector have been far fewer [11-13]. To sustain the positive growth, it is necessary to ensure the proper utilization of resources. Financial growth of any industry largely depends on minimizing excess work and productivity improvement. This study was masterful with some specific objectives which were to identify, quantify and to reduce the NVD activities and time towards the exalted PCE and therefore to reduce the lead time.

\section{METHODOLOGY}

The primary data was collected from personal observations of researchers of bi-fold wallet production lines at different production stages from a leading export-oriented leather products industry in Bangladesh. The secondary data was taken through the internet, books, journals, related studies and other sources of information. The methodology of carrying out this project work is divided into the following steps. In each of the steps, lean tools have been used which have been discussed in each section further [14].

\section{Process mapping $\longrightarrow$ Takt time calculating $\longrightarrow$ Lead time counting $\longrightarrow$ Bottleneck Analysis $\longrightarrow$ Cause-effect analysis $\longrightarrow$ Introducing time reducing technique $\longrightarrow$ Results}

\section{Process Mapping}

A process map is a planning and management tool that visually describes the flow of work [15]. Process maps show a series of events that produce an end result. It shows who and what is involved in a process and can be used in any business or organization and can reveal areas where a process should be improved [16]. There are many research articles that have discussed about the process mapping techniques used in various small and medium scale manufacturing industries [17]. The present \& proposed process mapping of bi-fold wallet production line are shown in the following Figures 1 \& 2. 


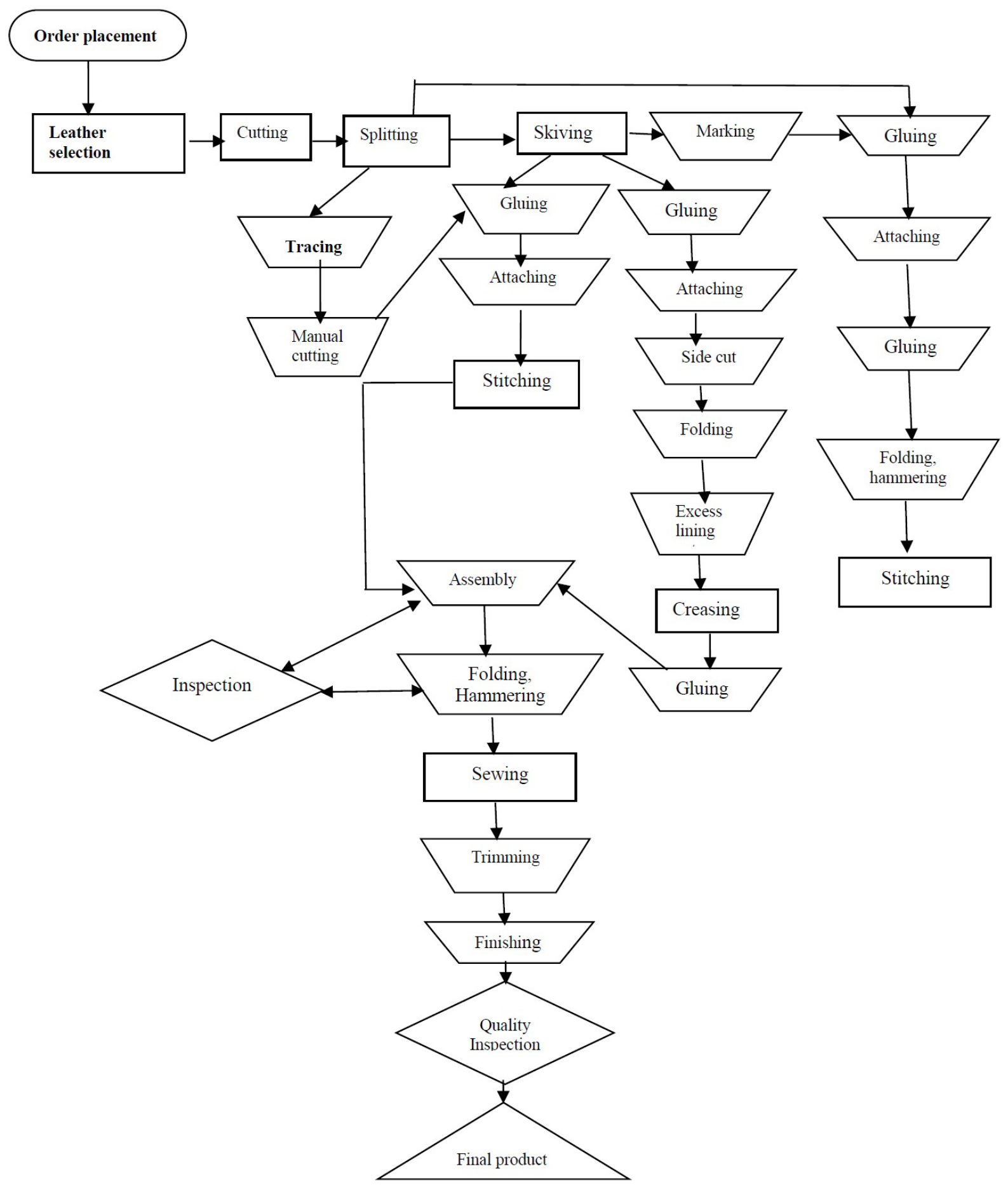

Figure 1. Present process mapping of bi-fold wallet production line 


\section{Proposed Process Mapping}

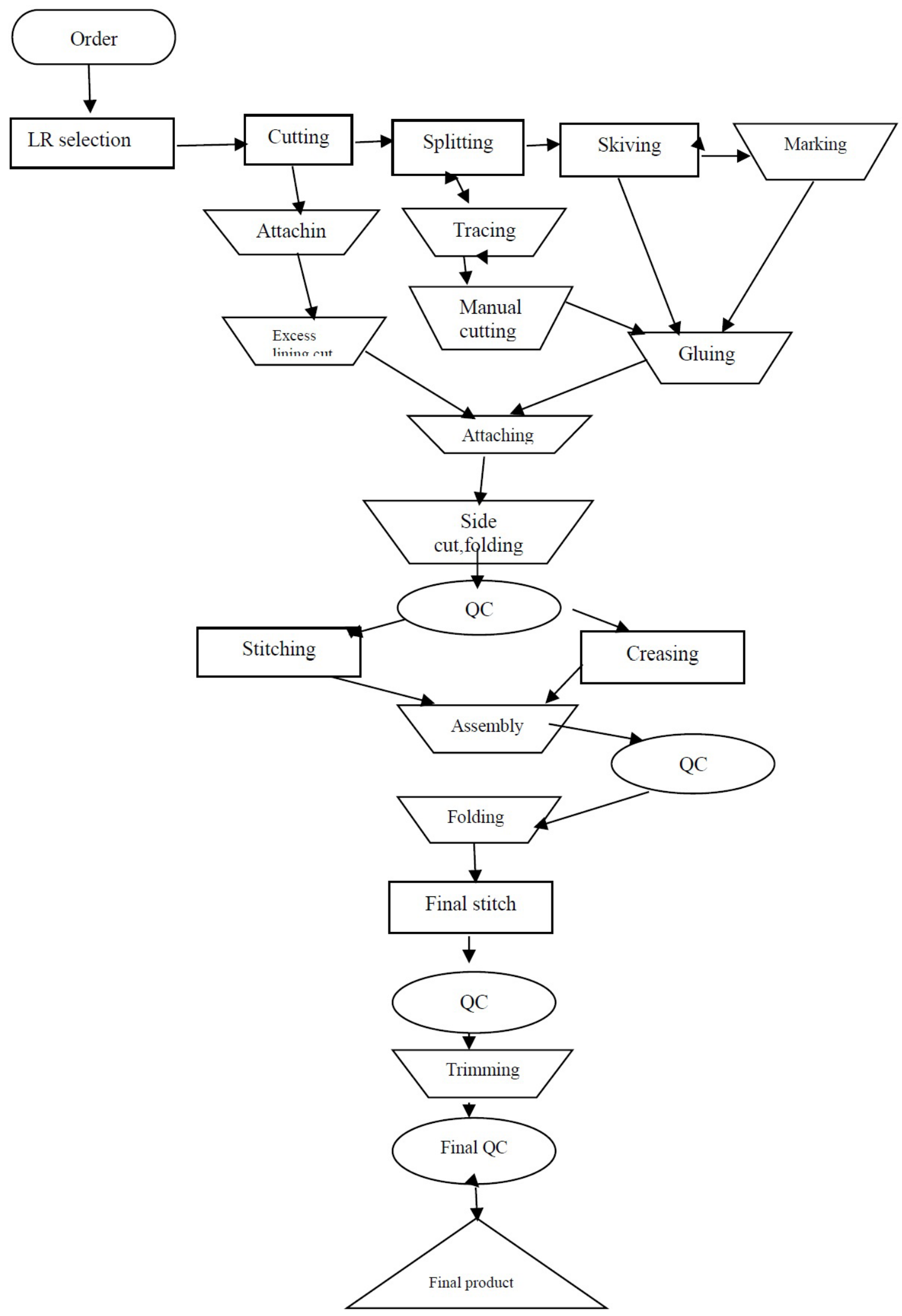

Figure 2. Proposed process mapping of bi-fold wallet production line 


\section{Takt Time Analysis}

Takt-time is the unit of time in which a product must be produced (supply rate) in order to match the rate at which that product is needed (demand rate) [18]. It is calculated by dividing the total available time per day by the daily customer demand:

Takt time $=$ Available work time/ Customer's demand

Available production time $=(7$ hours 45 minutes) $\times 8$

$$
=465 \times 8
$$

minutes

$$
=3720
$$

minutes wallet.

Customer's demand is 50 pcs of Double

\begin{tabular}{|c|c|c|c|c|c|c|c|c|}
\hline No & Operation name & $\begin{array}{c}\text { Average } \\
\text { cycle time } \\
\text { (sec) }\end{array}$ & $\begin{array}{c}\text { No. of } \\
\text { workers }\end{array}$ & $\begin{array}{l}\text { Waiting time } \\
\text { in seconds }\end{array}$ & $\begin{array}{c}\text { Total } \\
\text { waiting } \\
\text { time }\end{array}$ & $\begin{array}{c}\text { Process } \\
\text { gap time } \\
(\mathrm{sec})\end{array}$ & $\begin{array}{l}\text { No. of pcs } \\
\text { of work }\end{array}$ & $\begin{array}{l}\text { Total time } \\
\quad(\mathrm{sec})\end{array}$ \\
\hline 1 & Cutting leather, lining, net & 6 & 4 & & & & 1800 & 10800 \\
\hline 2 & Splitting leather & 4 & 1 & & & & 750 & 2823 \\
\hline 3 & Skiving & 12 & 1 & & & 86400 & 250 & 3000 \\
\hline 3 & Marking outer top & 50 & 1 & & & & 50 & 2500 \\
\hline 4 & Foam attaching on lining & 56 & 2 & & & & 50 & 2800 \\
\hline 5 & Excess lining cutting & 20 & 1 & 16 & 800 & & 50 & 1000 \\
\hline 6 & Gluing outer top & 25 & 1 & 25 & 1250 & & 50 & 1250 \\
\hline 7 & $\begin{array}{c}\text { Lining with foam attaching on outer } \\
\text { top }\end{array}$ & 9 & 1 & 19 & 950 & & 50 & 450 \\
\hline 8 & Adhesive applying on top side & 10 & 1 & 18 & 900 & & 50 & 500 \\
\hline 9 & Folding, hammering & 45 & 1 & & & & 50 & 2250 \\
\hline 10 & Stitching & 10 & 1 & & & 293 & 50 & 500 \\
\hline 11 & Gluing center piece & 20 & 1 & & & 293 & 100 & 2000 \\
\hline 12 & Center piece attaching on lining & 18 & 1 & 2 & 200 & & 100 & 1800 \\
\hline 13 & Stitching & 10 & 1 & 40 & 4000 & & 100 & 1000 \\
\hline 14 & Gluing on step pocket & 10 & 1 & & & 293 & 360 & 3600 \\
\hline 15 & Lining attaching & 6 & 1 & 4 & 1440 & & 360 & 2160 \\
\hline 16 & Top side folding, hammering & 40 & 2 & & & & 360 & 7200 \\
\hline 17 & Gluing on stamp pocket & 12 & 1 & 16 & 2400 & & 150 & 1800 \\
\hline 18 & Lining attaching & 6 & 1 & 22 & 3300 & & 150 & 900 \\
\hline 19 & Side cut for folding & 5 & 1 & 23 & 3450 & & 150 & 750 \\
\hline 20 & $\begin{array}{l}\text { Folding, hammering excess lining } \\
\text { cutting }\end{array}$ & 45 & 1 & & & & 150 & 6750 \\
\hline 21 & Inspection & 10 & 1 & 35 & 5250 & & 150 & 1500 \\
\hline
\end{tabular}

Table 1: Existing cycle time analysis of bi-fold wallet production line
Takt Time Formula $=3720 / 50=74.4$ minutes/wallet

In this research, after receiving order, the production process started and the final product (Double wallet) was delivered to the customer. The factory had 8 days to deliver 50 pcs of wallet, of which 1 day was off-day. The factory has a 9-hour workday for its workers and staffs, of which 1 hour is allocated lunch break, 15 minutes is wasted in the startup process in the morning.

\section{Data Analysis}

Information related to assembly line [1921] such as production time, inventory storages, inspections, rework loops, number of workers and operational hours per day were collected and documented in Tables 1 \& 2 .
Table 1: Existing cycle time analy 


\begin{tabular}{|c|c|c|c|c|c|c|c|c|}
\hline No & Operation name & $\begin{array}{c}\text { Average } \\
\text { cycle time } \\
\text { (sec) }\end{array}$ & $\begin{array}{c}\text { No. of } \\
\text { workers }\end{array}$ & $\begin{array}{l}\text { Waiting time } \\
\text { in seconds }\end{array}$ & $\begin{array}{c}\text { Total } \\
\text { waiting } \\
\text { time }\end{array}$ & $\begin{array}{c}\text { Process } \\
\text { gap time } \\
\text { (sec) }\end{array}$ & $\begin{array}{l}\text { No. of pcs } \\
\text { of work }\end{array}$ & $\begin{array}{c}\text { Total time } \\
\text { (sec) }\end{array}$ \\
\hline 22 & Creasing & 20 & 1 & & & 3750 & 150 & 3000 \\
\hline 23 & Window pocket tracing & 18 & 1 & & & & 50 & 900 \\
\hline 24 & Manual cutting & 88 & 1 & & & & 50 & 4400 \\
\hline 25 & Gluing on window pocket & 15 & 1 & 73 & 3650 & & 50 & 750 \\
\hline 26 & Net attaching on window pocket & 10 & 1 & 78 & 3900 & & 50 & 500 \\
\hline 27 & Side cut for folding & 5 & 1 & 85 & 4250 & & 50 & 250 \\
\hline 28 & Top side folding, hammering & 23 & 1 & 67 & 3350 & & 50 & 1150 \\
\hline 29 & Inspection & 18 & 1 & 72 & 3600 & & 50 & 900 \\
\hline 30 & Creasing & 20 & 1 & & & 350 & 50 & 1000 \\
\hline 31 & Gluing on both sides of step pocket & 5 & 1 & & & & 360 & 1800 \\
\hline 32 & Assembling 3 step pockets & 25 & 1 & & & & 120 & 3000 \\
\hline 33 & Stamp pocket placing & 12 & 1 & 17 & 850 & & 120 & 1440 \\
\hline 34 & Excess lining cutting & 20 & 1 & 11 & 550 & & 50 & 1000 \\
\hline 35 & Stitching & 10 & 1 & & & 4050 & 50 & 500 \\
\hline 36 & Assembling 2 step pockets & 15 & 1 & & & & 50 & 750 \\
\hline 37 & Window pocket placing & 20 & 1 & & & & 50 & 1000 \\
\hline 38 & Excess lining cutting & 22 & 1 & & & & 50 & 1100 \\
\hline 39 & Stitching & 5 & 1 & & & 2850 & 50 & 250 \\
\hline 40 & 1 step pocket, 1 cut pocket attaching & 40 & 2 & & & 405 & 100 & 4000 \\
\hline 41 & $\begin{array}{c}\text { Joining window and } 1 \text { cut pocket by } \\
\text { stitching }\end{array}$ & 10 & 1 & 17 & 850 & & 50 & 500 \\
\hline 42 & Assembling asther-1 & 50 & 1 & & & 285 & 50 & 2500 \\
\hline 43 & Assembling asther-2 & 50 & 1 & & & 300 & 50 & 2500 \\
\hline 44 & Joining by stitching & 10 & 1 & & & 2350 & 50 & 500 \\
\hline 45 & Attaching Asther on outer top & 55 & 1 & & & & 50 & 2750 \\
\hline 46 & Gluing three sides of outer & 20 & 1 & 35 & 1750 & & 50 & 1000 \\
\hline 47 & Folding, hammering & 62 & 1 & & & & 50 & 3100 \\
\hline 48 & Final stitching & 12 & 1 & 50 & 2500 & & 50 & 600 \\
\hline 49 & Trimming, thread cutting & 25 & 1 & 37 & 1850 & & 50 & 1250 \\
\hline 50 & Final checking & 50 & 1 & 12 & 600 & & 50 & 2500 \\
\hline \multirow[t]{2}{*}{51} & Packaging & 30 & 1 & 32 & 1600 & & 50 & 1500 \\
\hline & Total & 1244 & & & 53240 & 101619 & & 102373 \\
\hline
\end{tabular}

\section{Present Process Cycle Efficiency}

Process Cycle Efficiency (PCE) is measured as the percentage of ration of VD time and lead time, where lead time is the summation of value-added time (VD) and non-valueadded time (NVD) [22]. PCE is a measure of the relative efficiency in a process - it represents the percentage of value-add time (changing form, fit, function) of a product down the critical path.

Value added time $=102373$ seconds $=$ 28.44 hrs

Non-value-added time $=$ Set-up time + Total waiting time + Total process gap time 
$(10800+53240+101619)$ seconds $=165659$

seconds $=46.02 \mathrm{hrs}$

Lead time $\quad$ = Value added

time + Non-value-added time

$=$

$(102373+165659)$ seconds $=268032$ seconds $=$ $74.45 \mathrm{hrs}$

$\begin{array}{ll}\text { No. of worker } & =14 \\ \text { Productivity } & =0.048 \\ \text { PCE } & =\quad \text { (Customer }\end{array}$

Value Added Time $\div$ Process Lead Time) $\times 100 \%$

$268032) \times 100 \%=38.19 \%$

$$
=(102373 \div
$$

\section{Bottleneck Analysis}

The bottleneck of a production system is recognized as the machine that has the strongest impact on the overall system performance [23]. By definition, a bottleneck is a phenomenon where the competency of a complete system or line is restricted or limited by a single or limited number of components or resources and analysis of such event is called bottleneck analysis. Hence, bottleneck analysis is nothing but identifying which part/machine of the manufacturing process/line limits the overall output and focuses on improvement the performance of that part/ machine of the process/line [24]. Bottleneck analysis is usually done along with the Time Study Method. From the process map and cycle time analysis table, we can calculate the time required in each path.

Path-1: Splitting-Skiving-Making-GluingAttaching-Gluing-Folding-Stitching $=297$ seconds
Path-2:

Splitting-Gluing-AttachingStitching $=106$ seconds

Path-3: Splitting-Skiving-Gluing-AttachingSide Cut-Folding-Excess lining cut-Creasing $=270$ seconds

Path-4: Splitting-Skiving-Gluing-AttachingSide Cut-Folding-Excess lining cut-Creasing $=270$ seconds

Path-5: Splitting-Tracing-Manual CuttingGluing-Attaching-Side Cut-Folding-Creasing $=576$ seconds

Path-6: Creasing-Gluing-AssemblyFolding-Final Stitch-Trimming-FinishingInspection-Final product $=736$ seconds

Here, Path- 6 takes the longest period of time to complete one cycle. So, the Bottleneck is Path-6.

\section{Cause-Effect Analysis}

As the Ishikawa diagram is prior to any data analysis, every possible cause is taken into consideration. It is a visualization tool for categorizing the potential causes of a problem in order to identify its root causes [25]. Although it was originally developed as a quality control tool, it can be used just as well in other ways [26]. For instance, it can be used to discover the root cause of a problem, uncover bottlenecks in your processes, identify where and why a process is not working etc. Since we found that lead time is 88.8 minutes/wallet, whereas, takt time is 93 minutes/wallet; this is a serious problem that may cause huge delay in delivery. Therefore, we used Fishbone Diagram to find out possible cause behind this which is shown in the following Figure 3. 


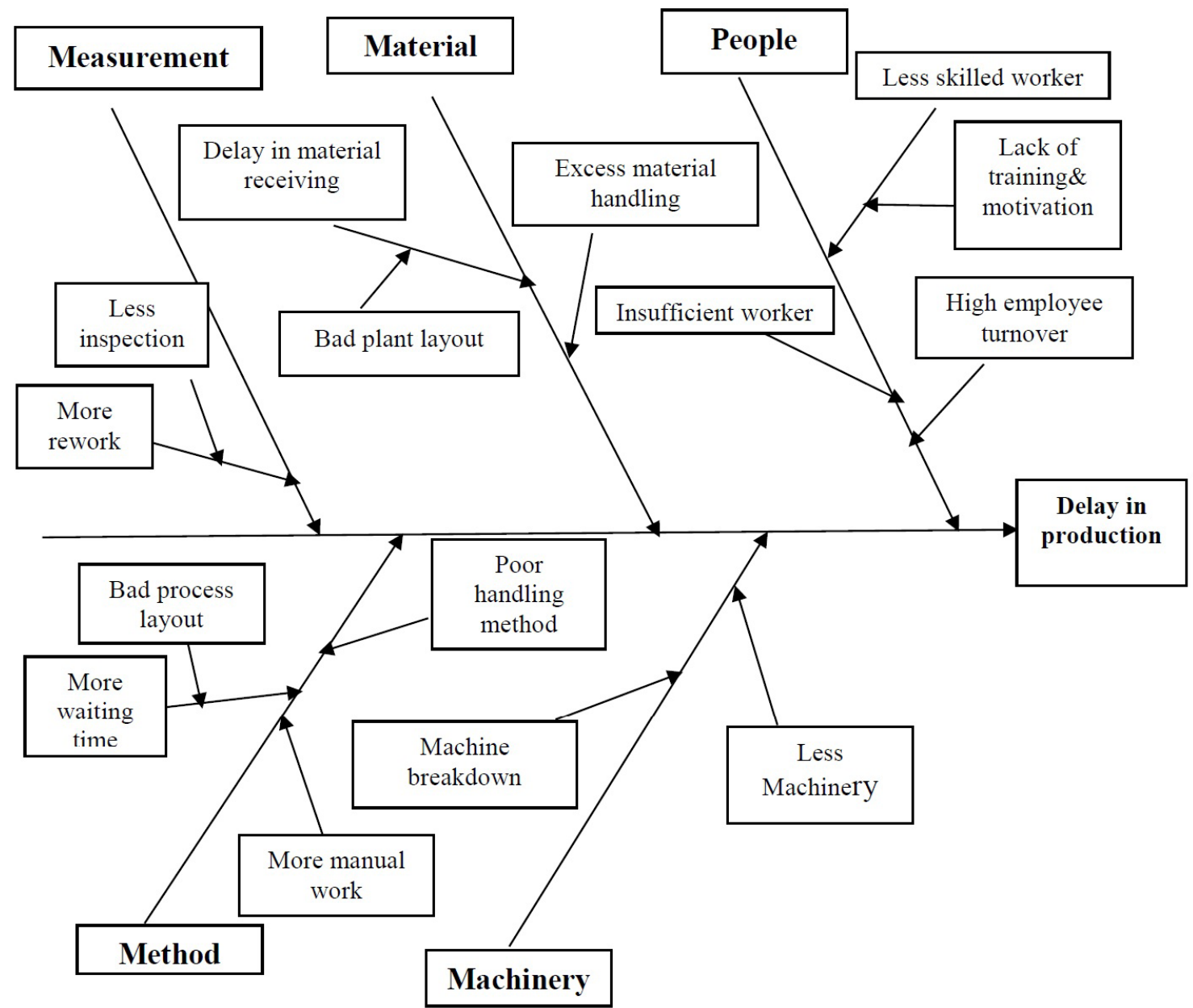

Figure 3. Cause-effect analysis of bi-fold wallet production line

\section{Pareto Analysis}

It is a statistical technique in decision making that is used for selection of a limited number of tasks that produce significant overall effect. It uses the Pareto principle - the idea that by doing $20 \%$ of work, $80 \%$ of the advantage of doing the entire job can be generated [27]. The Pareto Principle also known as the "80/20 Rule" which is the idea that $20 \%$ of causes generate $80 \%$ of results [28-30]. In this study, by using this tool it was tried to find out the $20 \%$ of causes that is generating $80 \%$ NVD activities. This tool focuses on the most damaging causes on a project.
In this essence, the application of the Pareto chart consisting of causes for downtime or NVD activities along the $X$ axis while the $Y$ axis represents the cumulative percentage of downtime. Most of the NVD activities were documented on sewing, pre-lasting, post-lasting and finishing steps where these were frequently observed due to different causes. The highest frequency of NVD activities that derived the down time were found for mainly needle \& threads breakage while the lowest frequency was varied shown in the following Figure 4. 


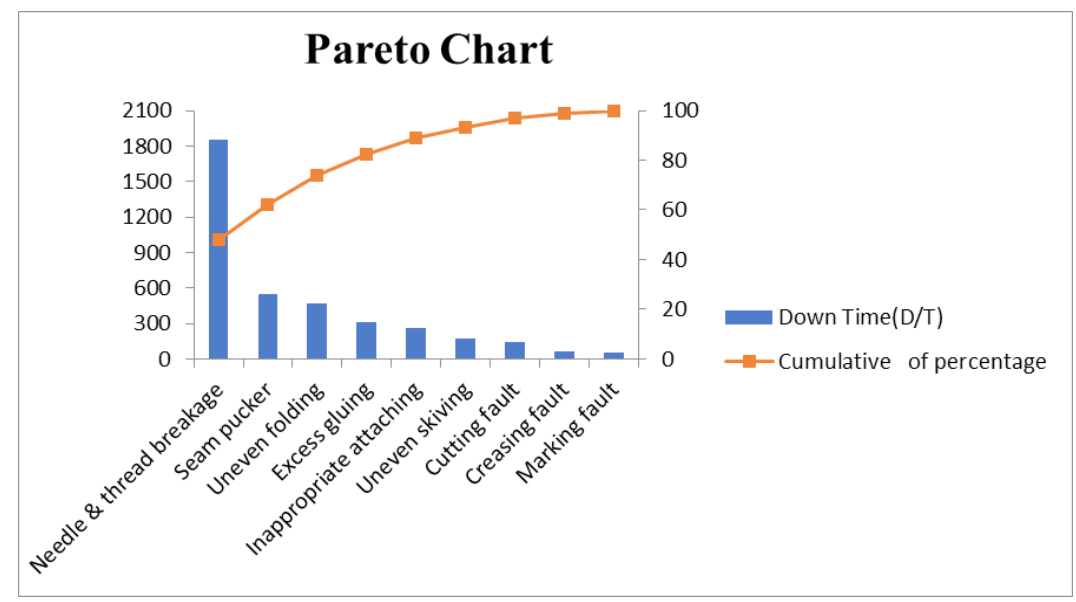

Figure 4. Pareto chart of bi-fold wallet production line

Table 2: Cycle time analysis for proposed way of bi-fold wallet production line

\begin{tabular}{|c|c|c|c|c|c|c|c|c|}
\hline No & Operation name & $\begin{array}{c}\text { Average } \\
\text { cycle time } \\
\text { (sec) }\end{array}$ & $\begin{array}{c}\text { No. of } \\
\text { workers }\end{array}$ & $\begin{array}{l}\text { Waiting } \\
\text { time (sec) }\end{array}$ & $\begin{array}{c}\text { Total } \\
\text { waiting } \\
\text { time }\end{array}$ & $\begin{array}{c}\text { Process } \\
\text { gap time } \\
\text { (sec) } \\
\end{array}$ & $\begin{array}{l}\text { No. of } \\
\text { pcs of } \\
\text { work }\end{array}$ & $\begin{array}{c}\text { Total time } \\
\text { (sec) }\end{array}$ \\
\hline 1 & $\begin{array}{c}\text { Cutting leather, lining, } \\
\text { net }\end{array}$ & 6 & 4 & & & & 1800 & 10800 \\
\hline 2 & Splitting leather & 4 & 1 & & & & 750 & 2823 \\
\hline 3 & Skiving & 12 & 1 & & & & 250 & 3000 \\
\hline 4 & Marking outer top & 50 & 2 & & & & 50 & 2500 \\
\hline 5 & $\begin{array}{l}\text { Foam attaching on } \\
\text { lining }\end{array}$ & 56 & 2 & & & & 50 & 2800 \\
\hline 6 & Excess lining cutting & 20 & 1 & 16 & 800 & & 50 & 1000 \\
\hline 7 & Gluing on outer top & 25 & 1 & & & & 50 & 1250 \\
\hline 8 & $\begin{array}{l}\text { Lining \& foam attaching } \\
\text { on outer top \& gluing } \\
\text { on top side }\end{array}$ & 19 & 1 & 6 & 300 & & 50 & 950 \\
\hline 9 & Folding, hammering & 45 & 1 & & & & 50 & 2250 \\
\hline 10 & Stitching & 10 & 1 & & & 237 & 50 & 500 \\
\hline 11 & Gluing center piece & 20 & 1 & & & 237 & 100 & 2000 \\
\hline 12 & $\begin{array}{l}\text { Center piece attaching } \\
\text { on lining }\end{array}$ & 18 & 1 & 2 & 200 & & 100 & 1800 \\
\hline 13 & Stitching & 10 & 1 & 10 & 1000 & & 100 & 1000 \\
\hline 14 & Gluing on step pocket & 10 & 1 & & & 237 & 360 & 3600 \\
\hline 15 & Lining attaching & 6 & 1 & 4 & 1440 & & 360 & 2160 \\
\hline 16 & $\begin{array}{l}\text { Top side folding, } \\
\text { hammering }\end{array}$ & 40 & 1 & & & & 360 & 14400 \\
\hline 17 & Gluing on stamp pocket & 12 & 1 & & & 237 & 150 & 1800 \\
\hline 18 & $\begin{array}{l}\text { Lining attaching \& side } \\
\text { cut }\end{array}$ & 11 & 1 & & & & 150 & 1650 \\
\hline 19 & $\begin{array}{l}\text { Folding, hammering } \\
\text { excess lining cutting }\end{array}$ & 45 & 1 & & & & 150 & 6750 \\
\hline 20 & Inspection & 10 & 1 & 19.36 & 2905 & & 150 & 1500 \\
\hline 21 & Creasing & 20 & 1 & & & & 150 & 3000 \\
\hline 22 & Window pocket tracing & 18 & 1 & & & & 50 & 900 \\
\hline 23 & Manual cutting & 88 & 2 & & & & 50 & 4400 \\
\hline 24 & $\begin{array}{c}\text { Gluing on window } \\
\text { pocket, net attaching \& } \\
\text { side cut }\end{array}$ & 30 & 1 & 14 & 700 & & 50 & 1500 \\
\hline
\end{tabular}




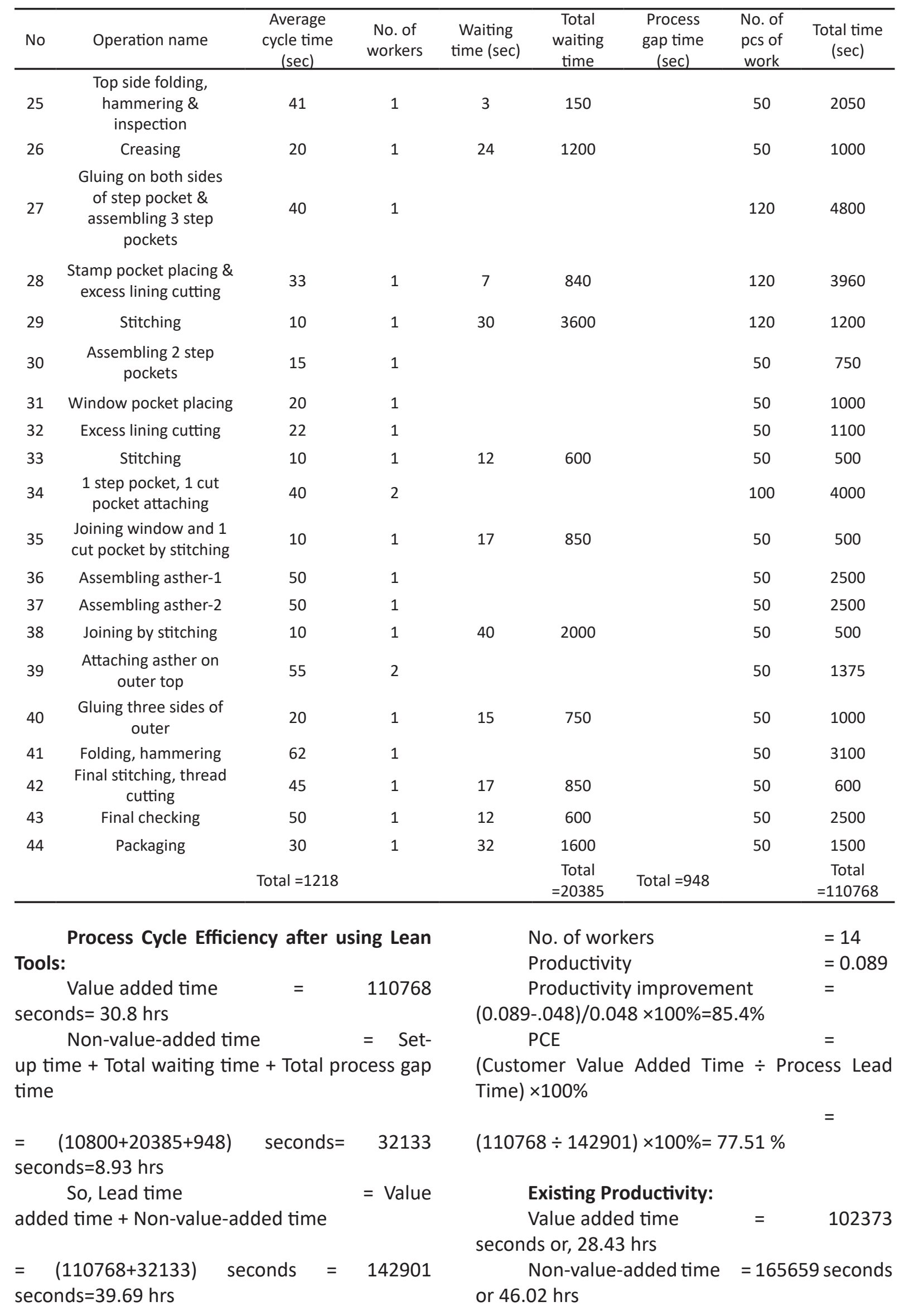


Lead time

seconds or 74.45 hrs

Productivity

Process cycle efficiency $=38.19 \%$

\section{Productivity after using Lean Tools:}

Value added time

$=110768$ seconds

or $30.77 \mathrm{hrs}$

Non-value-added time $=32133$ seconds or $8.92 \mathrm{hrs}$

Lead time = $\quad=142901$ seconds

or 39.69 hrs

$\begin{array}{ll}\text { Productivity } & =.089 \\ \text { Process cycle efficiency } & =77.51 \%\end{array}$

Results:

Productivity improvement $\quad=(.089-$

$.048) / .048 \times 100 \%=85.42 \%$

Lead time reduction

$=$

$(74.45-39.69) / 74.45 \times 100 \%=46.69 \%$

Value added time increased

$(30.77-28.43) / 28.43 \times 100 \%=8.23 \%$

Non- value-added time reduction $=$

$(46.02-8.93) / 46.02 \times 100 \%=80.59 \%$

PCE improvement

$=$

$(77.51-38.19) \%=39.35 \%$

\section{CONCLUSION}

The leather products industry is one of the key export-earning sectors in Bangladesh. Productivity improvement is a crucial matter in this industry. The profit earning of this industry totally rely on productivity improvement. The implementation of the lean concept in the leather products industry is primarily focused in order to reduce lead time and improve PCE. This model paves the way to ease implementation of lean concepts in leather products industry not only in Bangladesh but around the globe.

\section{REFERENCES}

1. Fisher, O., Watson, N., Porcu, L., Bacon, D., Rigley, M., Gomes, R.L., Cloud manufacturing as a sustainable process manufacturing route, J Manuf Syst, 2018, 47, 53-68, https://doi. org/10.1016/j.jmsy.2018.03.005.

2. Hossain, L., Sarker, S.K., Khan, M.S., Evaluation of present and future wastewater impacts of leather industries in Bangladesh, Fifth International Conference on Chemical
Engineering (ICChE 2017) Energy, Environment and Sustainability, BUET, Dhaka, Bangladesh.

3. Sayid Mia, M.A., Nur-E-Alam, M., Ahmad, F., Kamal Uddin, M., Footwear Industry in Bangladesh: Implementation of Six Sigma Methodology, Ind Eng Manage, 2017, 6, 211.

4. Sayid Mia, M.A., Nur-E-Alam, M., Lutfor Rahman, M., Kamal Uddin, M., Footwear Industry in Bangladesh: Reduction of Lead time by using Lean Tools, Journal of Environmental Science, Computer Science and Engineering \& Technology, Section C: Engineering \& Technology, 2017, 6, 3, 251259.

5. Nallusamy, S., Saravanan, V., Lean tools execution in a small-scale manufacturing industry for productivity improvement- A case study, Indian Journal of Science and Technology, 2016, 9, 35, 01-07.

6. Womack, J.P., Jones, D.T., Roos, D., The Machine that Changed the World, HarperCollins Publishers, New York, 1991.

7. Hobbs, D.P., Lean Manufacturing Implementation: A Complete Execution Manual for any Size Manufacturer, J. Ross Publishing, Boca Raton, 2004.

8. Sayid Mia, M.A., Nur-E-Alam, M., Kamal Uddin, M., Court Shoe Production Line: Improvement of Process Cycle Efficiency by using Lean Tools, Leather and Footwear Journal, 2017, 17, 3, 135-146, https://doi.org/10.24264/Ifj.17.3.3.

9. Saravanan, V. et al., Lead time reduction through execution of lean tool for productivity enhancement in small scale industries, International Journal of Engineering Research in Africa, 2018, 34, 116-127, https://doi.org/10.4028/www.scientific.net/ JERA.34.116.

10. Ramakrishnan, V., Nallusamy, S., Implementation of total productive maintenance lean tool to reduce lead time-A case study, International Journal of Mechanical Engineering and Technology, 2017, 8, 12, 295-306.

11. Saravanan, V., Nallusamy, S., George, A., Efficiency enhancement in a medium scale gearbox manufacturing company through different lean tools - A case study, International Journal of Engineering Research in Africa, 2018, 34, 128-138, https://doi.org/10.4028/ 
www.scientific.net/JERA.34.128.

12. Abdullah, F., Rajgopal, J., Lean Manufacturing in the Process Industry, Proceedings of the IIE Research Conference, CD-ROM, 2003, Portland, OR, IIE, Norcross, GA.

13. Sayid Mia, M.A., Nur-E-Alam, M., Ahmad, F., Kamal Uddin, M., Implementation of Lean Manufacturing Tools in Footwear Industry of Bangladesh, Aspects Min Miner Sci, 2017, 1, 1, https://doi.org/10.31031/ amms.2017.01.000503.

14. Dua, S., Xu, R., Huang, D., Yao, X., Markov modelling and analysis of multi-stage manufacturing systems with remote quality information feedback, Comput Ind Eng, 2015, 88, 13-25, https://doi.org/10.1016/j. cie.2015.06.012.

15. Rahani, A.R., al-Ashraf, M., Production flow analysis through value stream mapping: A lean manufacturing process case study, Procedia Eng, 2012, 41, 1727-1734, https:// doi.org/10.1016/j.proeng.2012.07.375.

16. Vinodh, S., Arvind, K.R., Somanaathan, M., Application of value stream mapping in an Indian camshaft manufacturing organization, J Manuf Tech Manag, 2010, 21, 7, 888-900, https://doi. org/10.1108/17410381011077973.

17. Nallusamy, S., Adil Ahamed, M.A., Implementation of lean tools in an automotive industry for productivity enhancement-A case study, International Journal of Engineering Research in Africa, 2017, 29, 175-185, https://doi.org/10.4028/www.scientific.net/ JERA.29.175.

18. Frandson, A., Berghede, K., Tommelein, I.D., Takt-Time Planning and the Last Planner, Production Planning and Control, Proceedings IGLC-22, June 2014, Oslo, Norway.

19. Holm, M., The future shop-floor operators, demands, requirements and interpretations, Journal of Manufacturing Systems, 2018, 47, 35-42, https://doi.org/10.1016/j. jmsy.2018.03.004.

20. Bawden, K.R., Williams, E.D., Babbitt, C.W., Mapping product knowledge to life cycle inventory bounds: a case study of steel manufacturing, J Clean Prod, 2016, 113, 557-564, https://doi.org/10.1016/j. jclepro.2015.10.014.

21. Rybicka, J., Tiwari, A., Campo, P.A.D., Howarth,
J., Capturing composites manufacturing waste flows through process mapping, J Clean Prod, 2015, 91, 251-261, https://doi. org/10.1016/j.jclepro.2014.12.033.

22. Zhen, Y., Food safety and lean Six Sigma Model, University of Central Missouri, 2011.

23. Li, L., A systematic-theoretic analysis of datadriven throughput bottleneck detection of production systems, Journal of Manufacturing Systems, 2018, 47, 43-52, https://doi. org/10.1016/j.jmsy.2018.03.001.

24. Leporis, M., Králová, Z., A simulation Approach To Production Line Bottleneck Analysis, International Conference in Cybernetics and Informatics, February 2010.

25. Rao, G.V.P., Nallusamy, S., Rajaram Narayanan, M., Augmentation of production level using different lean approaches in medium scale manufacturing industries, International Journal of Mechanical Engineering and Technology, 2017, 8, 12, 360-372.

26. Jefferson, O.A., Jaffe, A., Ashton, D., Warren, B., Koellhofer, D., Dulleck, U., Ballagh, A., Moe, J., DiCuccio, M., Ward, K., Bilder, G., Dolby, K., Jefferson, R.A., Mapping the global influence of published research on industry and innovation, Nat Biotechnol, 2018, 36, 1.

27. Pareto, V., Trattato di Sociologia GF, The Mind and Society, Dover, 1916.

28. Kimber, R.J., Grenier, R.W., Heldt, J.J., Quality Management Handbook, Marcel Dekker, NY, 1997.

29. Dyche, J., The CRM Handbook: A Business Guide to Customer Relationship Management, Addison-Wesley, 2001.

30. Arthur, L.J., Rapid Evolutionary DevelopmentRequirements, Prototyping \& Software Creation, John Wiley and Sons, 1992.

(C) 2018 by the author(s). Published by INCDTPICPI, Bucharest, RO. This is an open access article distributed under the terms and conditions of the Creative Commons Attribution license (http:// creativecommons.org/licenses/by/4.0/). 